\title{
FIRST REPORT OF Halkieria AND ENIGMATIC GLOBULAR FOSSILS FROM THE CENTRAL EUROPEAN MARIANIAN (LOWER CAMBRIAN, GÖRLITZ SYNCLINE, GERMANY)
}

\author{
Olaf ELICKI
}

Freiberg University. Geological Institute. D-09596 Freiberg. Germany.

E-mail: elicki@geo.tu-freiberg.de

Elicki, O. 1998. First report of Halkieria and enigmatic globular fossils from the Central European Marianian (Lower Cambrian, Görlitz Syncline, Germany). [Primer hallazgo de Halkieria y fósiles globulares enigmáticos del Marianiense de Europa central (Cámbrico Inferior, Sinclinal de Görlitz, Alemania)]. Rerista Espciñola de Paleontología, nº extr. Homenaje al Prof. Gonzalo Vidal, 51-64. ISSN 0213-6937.

\begin{abstract}
Some non-trilobite faunal elements from Marianian strata of eastern Germany ("Görlitz. Fauna" Lusatia) are presented from this region for the first time.

One of these is the Burgess type fossil Halkieria Poulsen, 1967. The extremely low frequency of halkieriids in the Görlitz fauna and, in contrast, the very large amount of chancelloriids in the same found horizon point to different habitats for these two coeloscleritophoran groups and support the assumption of different modes of life of these fossils.

Furthermore, a new report is made on six enigmatic and poorly preserved globular individuals assigned to Aetholicopalla adnata Conway Morris, 1990b. Nearly all of these globules show adaptions to a sessile benthic and/or to an encrusting mode of life.

Based on a portrayal of the present knowledge on higher Lower Cambrian small shelly faunas from central and southern Europe (Germany, Czechia, Poland, France, Spain, Italy) the utility of these fossil groups for biostratigraphy, palaeoecology and related topics are discussed. A prospect of the further tasks in the higher Lower Cambrian small shelly palaeontology of the western Mediterranean and especially the importance and the capability of related investigations in different regions of the Gondwanan European shelf is given.
\end{abstract}

Key words: Lower Cambrian, Marianian, small shelly fossils, halkieriids, Gondwana, Mediterranean region, Görlitz, Germany.

\section{RESUMEN}

Se da cuenta por primera vez de la presencia de elementos fósiles no trilobíticos en el Marianiense de Alemania oriental (Lusatia).

Uno de estos elementos es Halkieria Poulsen, 1967. constituyente de la biota de la Burgess Shale. que se encuentra aquí en la denominada "Fauna de Görlitz" por primera vez. La frecuencia extremadamente baja de halkieríidos en la "Fauna de Görlitz" contrasta con la gran cantidad de cancelloríidos que en ella se encuentra, lo que apunta a que estos dos grupos de celoscleritóforos preferían hábitats diferentes y tenían modos de vida distintos.

Además, se describen seis ejemplares mal conservados de fósiles globulares enigmáticos, atribuídos a Aetholicopalla adnata Conway Morris, 1990b. Casi todos ellos muestran adaptaciones a un modo de vida bentónico sésil y/o incrustante.

Trass la descripción del estado actual de conocimientos sobre faunas conchíferas del Cámbrico Inferior alto en Europa central y meridional (Alemania, República Checa, Polonia, Francia, España, Italia), se discute la utilidad de estos grupos fósiles en bioestratigrafía y paleoecología. Finalmente, se da una visión de las líneas futuras de investigación sobre la paleontología de estos grupos en el Cámbrico Inferior alto de la región mediterráneal occidental, especialmente la importancia de estudios análogos en otras regiones de la plataforma europea gondwánicá.

Palabras clave: Cámbrico Inferior, Marianiense, pequeños fósiles con concha, halkieríidos, Gondwana, región mediterránea, Görlitz, Alemania. 




Figure 1. Fossiliferous Lower Cambrian areas in Germany.

\section{INTRODUCTION}

Post-earliest Cambrian shelly fossils are generally known from all fragments of the European part of the Gondwanan shelf (for palaeogeography see CourjaultRadé et al., 1992). However, investigations were hitherto mainly focused on trilobites and archaeocyaths because of the better knowledge and the biostratigraphic value of these fossil groups. Other hard parts-bearing fossils (pelecypods, gastropods, monoplacophorans, ostracods, hyoliths, coeloscleritophorans, cambroclaves, eocrinoids, problematica) were investigated only sporadically. Reasons for this were: 1) the unabilty to prepare the samples, especially the calcareous remains from the fossil bearing lithotypes which are mostly limestones and dolostones; 2) the lack of possibilities for investigating these "not preparable" fossils by thin sections; and 3) the main applied palaeontological interest, which lays clearly on the fields of biostratigraphy and correlation, and so the preferred fossil groups were the trilobites and the archaeocyaths.

On the other hand the knowledge of the post-basal Cambrian so called "small shelly fossils" (or "early shelly fossils") shows a distinct increase worldwide during the last years (the term "small shelly fossils" was originally introduced by Matthews and Missarzhevski (1975) for phosphatic microfossils of Early Cambrian strata but later it has been often used also for secondary phosphatized and calcareous remains of early Palaeozoic age). So many findings were notified and investigated from Siberia, North America, Australia, Asia and other places (for examples and further references: Missarzhevski,
1989; Bengtson et al., 1990; Kruse, 1990; Qian and Bengtson, 1989; Cowie and Brasier, 1989; Landing et al., 1989). In central and southern Europe such faunas were reported from France (Montagne Noire), Italy (Sardinia), Spain, Czechia, Poland and Germany (see below).

The aim of this paper is to present the first Burgess type fossil and some other taxa from the German Lower Cambrian "Görlitz Fauna" (Marianian in age) and to look out for the utility of these fossils and for the future tasks of the work on this very interesting but still poorly known group in the European regions cited above.

\section{LOWER CAMBRIAN EARLY SHELLY FOSSILS IN CENTRAL AND SOUTHERN EUROPE}

Trilobite remains are known from the Lower Cambrian of Germany for a long time (Richter and Richter, 1923). On the other hand, hard parts of nontrilobite fossils of this age were discovered many years later and they were never object of detailed investigations up to the end of the eighties.

A historical overview as well as many new results of investigations on shelly fossils from the German Lower Cambrian rocks were published by Elicki and Schneider (1992) and Elicki (1994, 1996).

Whereas the older Doberlug biotas (Lower Cambrian subsurface deposits near Leipzig; Fig. 1) are clearly dominated by cyanobacteria and archaeocyaths (Elicki and Debrenne, 1993; Elicki, unpublished data), the carbonate sequence of Görlitz (near the border to Poland; Fig. 1) contains biotas characterized by the dominance of shelly fossils. More than $90 \%$ of the whole fossil content is represented by hyoliths. Trilobites, brachiopods, mollusks, and problematica (as Rhombocorniculum, Coleoloides, Microcoryne, cambroclaves and others) are only the minor fossil content. The number of the very frequent but always isolated echinoderm, poriferan, and chancelloriid remains is remarkable. (Because of the disarticulation the total number of these fossil organisms can not be given. However, the role of these biotas within the Görlitz fauna have been considerable.) The character of the fauna varies through the section. So, from the overlaying siliciclastics only trilobites, brachiopods and hyoliths are known (Geyer and Elicki, 1995).

Shelly fossil assemblages are also known from the Czechian region (Bohemia). The classic area is the Barrandean in the southern region of Prague with its famous Middle Cambrian deposits. Trilobite dominated faunas are very well known from here. But, for example, hyoliths, brachiopods and echinoderms do also occur.

From the mainly conglomeratic and coarse grained Lower Cambrian strata only some shelly fossils within a thin shaly intercalation (Paseky Shale; review and further references by Śtorch et al., 1993) are preserved. The shelly fossil content consists exclusively of non-trilobite arthropods of a non-marine (brackish?) environment (Chlupáč, 1995). The dominating taxon Kodymirus vagans Chlupáč and Havlíček, 1965 (a chelicerate 
arthropod) is known for more than 30 years. Two further taxa were firstly described only some years ago: the merostome Kockurus grandis Chlupác, 1995, and the phyllocarid Vladicaris subtilis Chlupáč, 1995. The stratigraphic age of these fossiliferous layers can be assumed by their lithostratigraphic position between the Proterozoic strata (situated below the basal Cambrian conglomerates and affected by the Cadomian orogeny) and the early Middle Cambrian marine faunas (see above). New investigations on cyanobacteria, algae, acritarchs, and other non-skeletal remains support this assumption (Fatka and Konzalova, 1995).

A noticeable Cambrian fauna is also known from Poland. So, Gondwana-related higher Lower Cambrian non-trilobite hard parts remains were found in the Holy Cross Mountains as well as in the Kaczawa Mountains. In the Czarna Shale and in the Ociesęki Sandstone of the Holy Cross Mountains hyoliths, merostomes, pelagiellids and problematica (as Sabellidites, Coleoloides, Platysolenites and others) occur (for units and references see Orłowski, 1975, 1985; Lendzion et al., 1982; Kowalski, 1983; OrXowski and Waksmundzki, 1986).

The Lower Cambrian age of sequences of the Kaczawa Mountains is mainly based on lithostratigraphic arguments. The large lithological similarities between carbonates of the Kaczawa Mountains and the fossiliferous Lower Cambrian strata of the Görlitz region (easternmost Germany, see above) are remarkable. However, there are also some lithological differences between these regions (terrigenous influx in the Görlitz region and large volcanism in the Polish sections) so that these lithostratigraphic arguments are problematic by the opinion of the author. The fossil content found so far is represented only by phyllocarids (Silesicaris nasuta Gürich, 1929) and problematica. Lorenc (personal communication and own observations by the author) has demonstrated the presence of poorly preserved trilobite remains from thin sections of the carbonates.

Gèze (1956) has given an overview of the Cambrian of the Montagne Noire (France) including the fossil content (e.g. non-trilobite arthropods, hyoliths, Torellela). From the southern part of the Montagne Noire, CourjaultRadé (1988), in a sedimentological focused paper, has reported chancelloriids and echinoderms.

Kerber (1988) has published on Lower Cambrian microfossils from the end members of a carbonate depositional sequence (phosphatic "Heraultia limestones") of the northern Montagne Noire. In his extensive account he has described 34 species of hard part-bearing fossils from 28 non-trilobite genera. So, up to day, this publication represents the most important compilation for such Lower Cambrian shelly microfossils from France. The faunal diversity reaches from hyoliths (circothecids and globorilids) to crustaceans (branchiopods), annelids? (Cambrotubulus), coeloscleritophorans (halkieriids), mollusks (gastropods), brachiopods, and systematically problematic taxa as Archaeooides, Paracarinachites, Cambroscutum, Aculopileus and a new introduced group of "Torimorphidae" (containing Rozanoviella, Maikhanella, and others). The age of the fossil bearing horizons is comparable to the uppermost Atdabanian-Botoman.

Similar fossils [coeloscleritophorans, hyoliths, gastropods (Aldanella) and non-trilobitic arthropods] are also known from Normandy, northern France [see Doré (1969), Doré and Reid (1965), and Pillola (1993) for ${ }^{-}$ further references].

Cambrian deposits are also widespread in southwestern Sardinia (Italy; for references see the standard monograph edited by Bechstädt and Boni, 1994). Palaeontological investigations, however, were hitherto carried out mainly on trilobites and archaeocyaths. Other fossil groups were mostly mentioned nearby (for example, Bornemann, 1886, 1891; Pillola, 1991). Only sporadically some workers have engaged in hard parts of these other fossil groups. So Cherchi and Schroeder (1984) have described some foraminifera, poriferans, chancelloriids and problematica [as Hadimopanella (=Lenargyrium)] from a Lower/ Middle Cambrian boundary interval (Iglesias Group, type section of the Campo Pisano Formation near Iglesias). Maybe the stratigraphic position of the bearing horizons is always lower Middle Cambrian but, nevertheless, the palaeoecological position as well as the sedimentary tendency of this interval can be well compared with higher Lower Cambrian successions elsewhere in central and southern Europe. Mostler (1985) has reported further findings from the nodular limestones of the same formation and from Lower Cambrian archaeocyathan limestones. From insoluble remains of the older of these layers, mainly sponge spicules were obtained but also brachiopods, bad preserved "ostracode shells" and hyolithelminths. Samples of the Campo Pisano Formation have shown echinoderm plates (eocrinoids, rare carpoids, and probably ophiures), paraconodonts, and problematica (Lenargyrium, Olivsides, Zeugites and unnamed "others"). Further, different authors have mentioned chancelloriids, echinoderm and poriferan remains as components in thin sections of the Lower Cambrian material. At present the shelly fauna of the carbonates of the Campo Pisano Formation are under palaeontological research by the author.

From the southwestern Mediterranean (Iberian Peninsula), Lower Cambrian trilobites and archaeocyathan faunas are known and well investigated since a long time, but publications on the other shelly fossil content are hitherto rather rare (e.g. chancelloriids by Sdzuy, 1969). In their Lower to Middle Cambrian stage revision for the Iberian Peninsula, Liñán et al. (1993) have mentioned chancelloriids, pelagiellids, brachiopods, and others from the Spanish Lower Cambrian (see also Liñán and Quesada, 1990, for references of the older literature). Newer findings of chancelloriids and sponge spicules from the Lower-Middle Cambrian boundary interval in northeastern Spain (Iberian Chains) were published by Álvaro and Vennin (1996), and findings of chancelloriids, Hyolithellus and Torellela from southern Spain (Sierra de Córdoba) by Férnández-Remolar (1996). At present, Spanish Lower Cambrian shelly faunas are in investigation by the last author. 


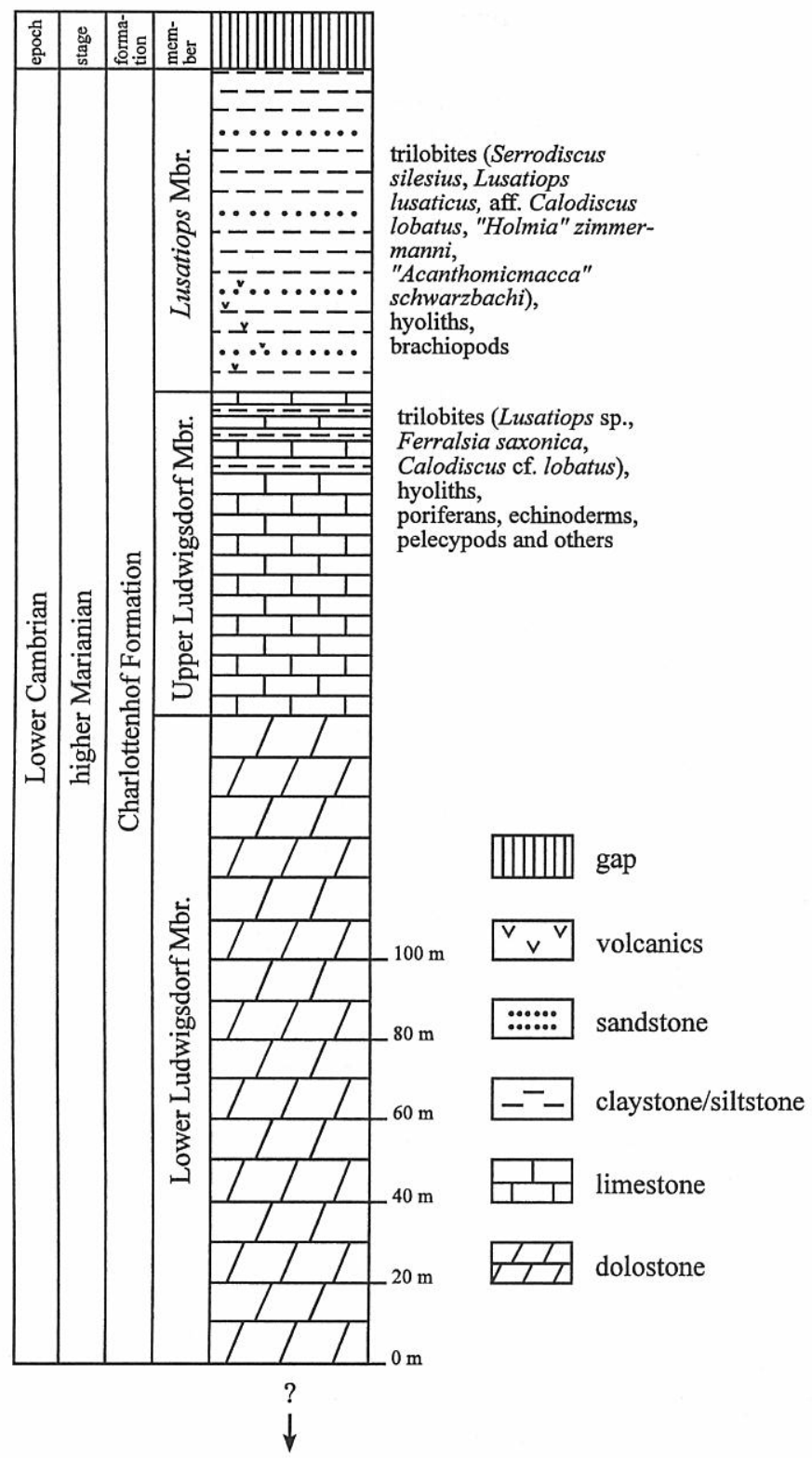

Figure 2. General section of the Görlitz Lower Cambrian succession. (Modified after Elicki, 1997.)

\section{STRATIGRAPHY}

All specimens described below were found in one layer. This horizon is situated above massive intertidal to shallow subtidal dolostones (Lower Ludwigsdorf Member), within a shallow subtidal sequence of limestones (Upper Ludwigsdorf Member) overlain by fine-grained siliciclastics (Lusatiops Member, see Elicki, 1994, 1997; Fig. 2). The fossils occur in a light-yellow to red and slightly sandy bioclastic floatstone which also contains some phosphatic pebbles (Pl. I, figs. 1,2). Within this layer small channels, ripple marks and cut-and-fill structures are observed. Based on sedimen-tological criteria, the general depositional tendency of the whole Lower Cambrian Görlitz section (Ludwigsdorf Member and Lusatiops Member) is transgressive. However, within the carbonate portion (Ludwigsdorf Member) some short- time shallowing trends of a minor order can be observed (Elicki and Schneider, 1992).

Within the Görlitz Lower Cambrian strata only shelly fossils and cyanobacteria occur (Elicki 1994, 1996). Archaeocyaths are hitherto unknown from this area (but some very rare, small and disturbed grid-like remains maybe skeletal parts of these aspicular sponges - were observed). The character and the succession of faunal assemblages occurring in the carbonate sequence is described by Elicki (1994). It is remarkable that both the halkieriid remains and the globular fossils were found in the layer which shows the largest faunal diversity and which is situated directly below the only horizon yielding Rhombocorniculum cancellatum (Cobbold, 1921). The remains occur together with hyoliths, poriferans, echinoderms, trilobites and pelecypods (these five groups represent $96 \%$ of all fossils). Furthermore, they are also accompanied in minority by gastropods, monoplacophorans, brachiopods, cambroclaves and other problematica (as Microcoryne cephalata Bengtson, 1990, and Coleoloides typicalis Walcott, 1890; see Elicki, 1994).

Following the biostratigraphic position of the trilobite fauna [Calodiscus cf. lobatus (Hall, 1847), Lusatiops sp., Ferralsia saxonica Geyer and Elicki, 1995] and of the shelly fossil assemblages, the age of the fossiliferous carbonate sequence (Upper Ludwigsdorf Member) is Marianian (comparable to the uppermost Atdabanian of the Siberian subdivision; compare Elicki, 1994, 1997, and Geyer and Elicki, 1995). The age of the overlaying siliciclastics [Lusatiops Member with Serrodiscus silesius Richter and Richter, 1941, aff. Calodiscus lobatus (Hall, 1847), "Holmia" zimmermanni (Schwarzbach, 1939), Lusatiops lusaticus (Schwarzbach, 1934) and "Acanthomicmacca" schwarzbachi (Richter and Richter, 1941)] is only little younger: higher Marianian (comparable to the Siberian Botoman Stage; Liñán and GámezVintaned, 1993).

\section{SYSTEMATIC PALAEONTOLOGY}

All the palaeontological material is housed in the Geological Institute of the Freiberg University, Germany (archives no. 410).

\section{HALKIERIIDS}

Halkieriids represent a group of the Cambrian polyphylethic coelosclerithophorans (sensu Bengtson and Missarzhevski, 1981) indicated by a special type of small sclerites showing variable geometries and surface structures (see definition below). The family Halkieriidae as well as the genus Halkieria were established by Poulsen (1967) on specimens from the Bornholm Lower Cambrian strata.

Despite of the long time since this first description of such fossil remains, the knowledge on their stratigraphic utility and systematics is rather poor. In this sense Conway Morris (1990a) has discussed these problems as caused by taxonomy on incomplete and/or poorly 
preserved specimens. Reconstructions of the halkieriid animal are mainly based on articulated material of Wiwaxia corrugata Matthew, 1899, found in the Burgess Shale (British Columbia, Canada). However, spectacular new findings of well preserved articulated specimens from the Lower Cambrian Buen Formation of northern Greenland led to a larger clearness but also to surprising insights on the anatomy of these fossils (Conway Morris and Peel, 1990; Conway Morris, 1995). For these complete preserved halkieriid animals a mean length of about $50 \mathrm{~mm}$ is given (Conway Morris and Peel, 1990). Their slug-like bodies were covered by different types of imbricating sclerites. On the dorsal side palmate (scaleshaped blade, slit-like foramen), on the lateral side cultrate (knife-shaped blade, foramen rounded, triangular or rhombic) and on the ventrolateral side spiniform (rounded triangular to lentiform blade, foramen small and round) elements have been observed (Bengtson and Conway Morris, 1984). The different shapes and numbers of the blade types, as well as the comparison with the Burgess Shale taxon Wiwaxia corrugata Matthew, 1899, led to the interpretation that these sclerites had mainly a protective function (Bengtson and Conway Morris, 1984; Conway Morris, 1990a). Jell (1981) has argumented metabolic functions for these skeletal elements: he has assumed that protection was only a minor function of the sclerites, but vital functions as facilitate the respiration or absorption and digestion can be also expected. The systematic position of the halkieriids is quiet dark. Maybe they should be grouped together with annelids, brachiopods or mollusks (Jell, 1981; Conway Morris and Chapman, 1997).

\section{PHYLUM UNKNOWN}

?CLASS COELOSCLERITOPHORA Bengtson and Missarzhevski, 1981

\section{ORDER UNKNOWN}

Family Halkieriidae Poulsen, 1967

Type genus: Halkieria Poulsen, 1967.

Diagnosis: Bilaterally symmetrical metazoans with a slug-like body, mantled by inbricating asymmetrical scale-shaped sclerites (calcareous or phosphatic blades). The sclerites have a central cavity which forms on the base a ventral foramen of different shape. The blades surfaces are usually ornamented by longitudinal ribs and transverse striations.

\section{Genus Halkieria Poulsen, 1967}

Type species: Halkieria obliqua Poulsen, 1967.

Diagnosis: Mainly cultrate and palmate (only in some cases spiniform) sclerites; central canal (cavity) present;
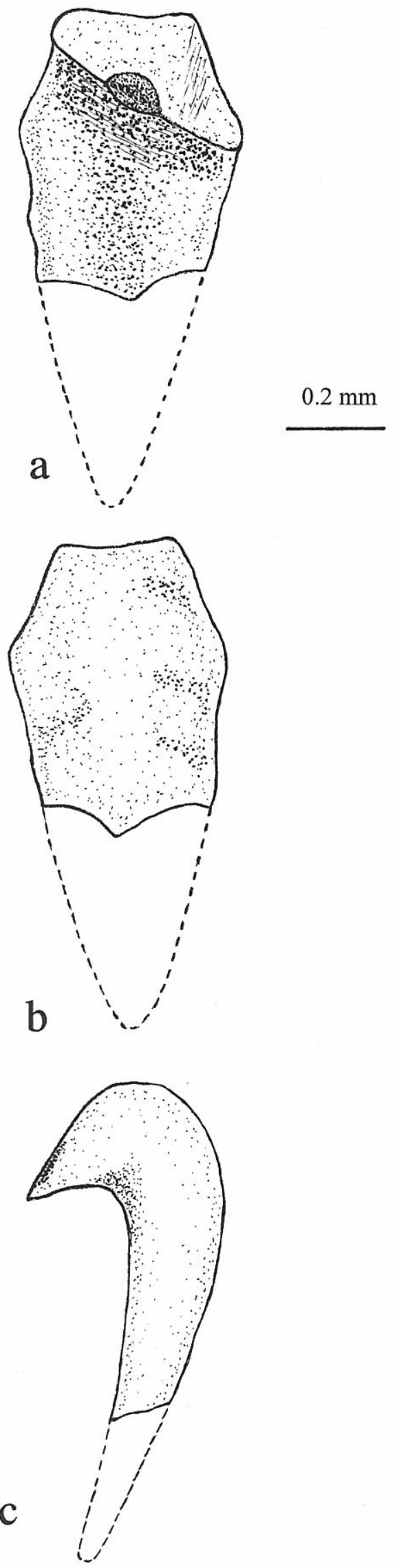

Figure 3. Halkieria sp. from the Görlitz fauna. Scale bar $=0.2 \mathrm{~mm}$. $\bullet$ a. ventral view. $\bullet$ b. dorsal view. $\bullet$ c. lateral view. 
upper surface ribbed and with ornamentation; lateral camerate structures.

Stratigraphic range and occurrence: Lower Cambrian of Denmark, England, France, Germany, Kazakhstan, Pakistan, Siberia, Mongolia, China, Australia, SE Newfoundland, U.S.A. and Antarctica.

\section{Halkieria sp.}

Fig. 3; Pl. I, figs. 3-5

Material: Only one incomplete specimen from a bioclastic floatstone deposited within a shallow subtidal environment (compare Elicki, 1994, 1996).

Stratigraphic range and occurrence: Upper Ludwigsdorf Member, Marianian age (?uppermost Atdabanian/Botoman) based on trilobites (Geyer and Elicki, 1995) and early shelly fossils (Elicki, 1994).

\section{Description}

The specimen is represented by a broken sclerite remain. The asymetrical cultrate blade has an assumed length of approximately $1.0 \mathrm{~mm}$ (length of the broken remain $=0.6$ $\mathrm{mm}$ ) and a width of $0.4 \mathrm{~mm}$. The estimated length:width ratio of the complete specimen is at least 2.5. Its geometrical shape is knife-like, flat and strongly curved. The base of the sclerite is prominent. Curvature of the blade towards the ventral side is clearly remarkable. The central canal is only visible by the foramen. This terminal foramen has a halfround to subtriangular geometry and is placed in the middle of the base. Surface sculpture is pronounced by only one (hard to) visible and weakly developed longitudinal rib on the dorsal side. On the ventral side of the blade a striation nearly in right angles to the blade axis is visible (Pl. I, fig. 5).

\section{Discussion}

The halkieriid remain discussed herein has a too bad preservation for the identification at the taxonomic species level. However, the observation of this first halkieriid in the central European Lower Cambrian is important for the biofacies diversity and for comparison of the Görlitz fauna with other Lower Cambrian shelly communities of the Gondwana shelf (see below).

From all the known halkieriids, the Görlitz halkieriid resembles mostly the specimens described by Kerber (1988) as "Halkieria sp. 2" from the Montagne Noire (France). The asymmetrical shape, the low axial torsion of the blade which is restricted to the proximal end, and the simple ornamentation of the dorsal side (only one median ridge) as well as the ventral transverse striation are observed on specimens both from southern France and from Germany. Moreover, Kerber could not identify any lateral chambers, as it happens with the German material.

Roughly similarities due also exist to the halkieriid Halkieria stenobasis (Jiang in Luo et al., 1982) described from South China by Qian and Bengtson (1989). So the characteristics in the symmetry, in the dimensions, in the general geometry and angles are remarkably coincident. In contrast to the Chinese material, however, the German specimen has no several longitudinal ribs on the dorsal side.

Nevertheless, all these differences do not permit to introduce a new taxon because of the limited number and the poor preservation of the material. New findings from the Görlitz fauna and more basic work on all halkieriids are necessary to demystify the systematics of this very interesting group.

\section{GLOBULAR FOSSILS}

Lower Cambrian globular fossils are widely distributed [China (Qian, 1977), France (Kerber, 1988), Mongolia (Val'kov, 1987), Siberia and Kazakhstan (Rozanov, 1982; and Missarzhevski, 1989), Australia (Bengtson et al., 1990), Germany (Elicki and Schneider, 1992)] and they do often represent so-called "problematica". Reasons for their functional, palaeobiological and systematic obscurity are the (maybe original) low amount of fossilizable structures (hard parts), the large discrepancies in preservation of the specimens, and at least the often only inexact descriptions which led to many different "species". So many of these Lower Cambrian "species" seem to represent synonyms (for a discussion of synonymy see Qian and Bengtson, 1989, and Conway Morris, 1990b).

\section{Plate I}

1 Thin section of the fossiliferous limestone yielding the fossils discussed in the text. Note the chancelloriid (Archiasterella) upper right. Upper Ludwigsdorf Member, Görlitz Syncline. Scale bar=2 $\mathrm{mm}$.

2 Another thin section of the lithotype also pictured in (1). Note the high and unbroken fossil content (mainly hyoliths and trilobites). Upper Ludwigsdorf Member, Görlitz Syncline. Scale bar=5 mm. (After Elicki and Schneider, 1992.)

3-5 Halkieria sp. Ventral view. Note the transversal striations on the ventral side of the blade in (5). Upper
Ludwigsdorf Member, Görlitz Syncline. Scale bar=0.1 $\mathrm{mm}$.

6-9 Aetholicopalla adnata Conway Morris, 1990b. Upper Ludwigsdorf Member, Görlitz Syncline. • 6. Specimen «a». Note the double wall structure, the encrusting habit, the tubules and the reticulate ornamentation on the surface of the inner wall. Scale bar=0.2 $\mathrm{mm}$. 7 . Detail of (6). Scale bar $=0.05 \mathrm{~mm}$. -8 Specimen «b». Note the encrusting habit and the longitudinal sections of the vermiform tubes running irregular into the interior of the globule. Scale bar=0.2 mm. 9. Detail of (8). Scale bar $=0.1 \mathrm{~mm}$. 
Plate I

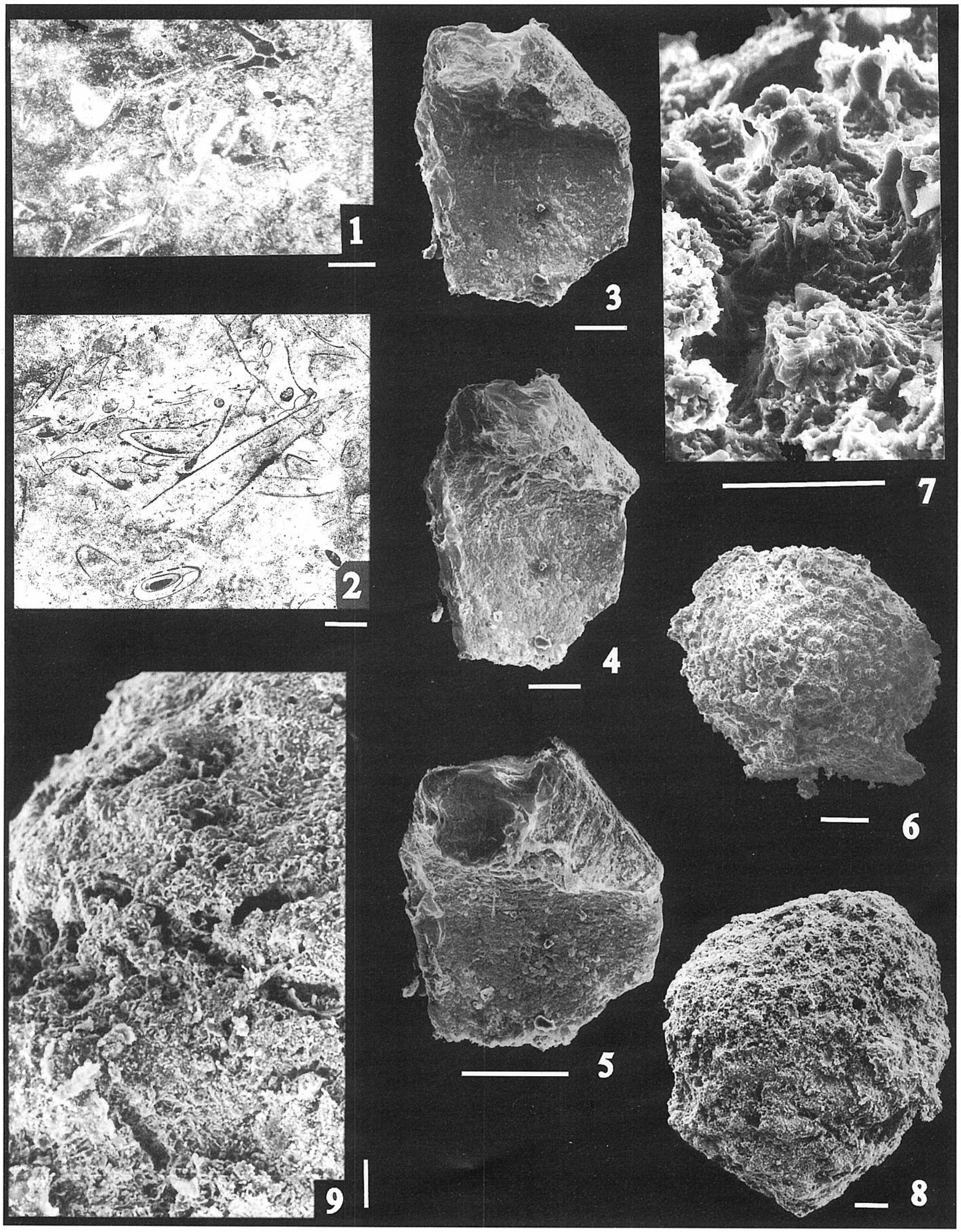

Revista Española de Paleontología, no extr. Homenaje al Prof. Gonzalo Vidal, 1998. 
A lot of these globular fossils, however, show a distinct surface structure. This structure consists mostly of a remarkable porosity. So Archaeooides Qian, 1977, Gaparella Missarzhevski, 1981, Aetholicopalla Conway Morris, 1990b, Blastulospongia Pickett and Jell, 1983, diverse "problematica" (for instance in Val'kov, 1987: pl. 14, fig. 15) and others (see the fossil list given by Conway Morris, 1990b) show this porosity. Following the critical analysis of synonymy mentioned above, among these more than ten taxons only Archaeooides Qian, 1977, Aetholicopalla Conway Morris, 1990b and Blastulospongia Pickett and Jell, 1983 seem to represent real different taxons. The main difference between Blastulaspongia and the other two globular fossils consists in the wall material which is siliceous in the last mentioned genus but most possible calcareous (sometimes secondary phosphatized) in the others. The distinction between Archaeooides and Aetholicopalla is sometimes difficult if the preservation of the specimens is not excellent. Archaeooides has a more or less spherical shape, it is hollow, porous and at times it shows tubules on the surface. In contrast, Aetholicopalla is double walled and has a central cavity which is filled by vermiform tubes. Furthermore, the inner wall and the space between the two walls are characterized by distinct features (compare Conway Morris, 1990b). However, the same author points out problematic similarities of these two fossils, in the case that the outer wall of Aetholicopalla is not preserved and so the exterior surface of the inner wall can looks like Archaeooides. Unfortunately, no minute ornamentation features are discribed from Archaeooides and it is not shure if they are present or not on the specimens hitherto known. An important difference seems to lay in the mode of live: so, because of the general shape and of many attached components and substrates, for Aetholicopalla an encrusting lifestyle is assumed (Conway Morris, 1990b).

The stratigraphic occurence of Archaeooides, Aetholicopalla, and Blastulaspongia is Lower Cambrian, maybe focused on the Tommotian to Botoman interval.
For a discussion of the systematic position of these globular fossils see Conway Morris and Chen, 1990; Bengtson et al., 1990, and cited literature).

Six specimens of globular fossils with an ornamented surface were found in the Görlitz fauna so far (Pl. I, figs. 6-9; Pl. II, figs. 1-8). Their preservation is not very good. Having not knowledge of the taxonomic work of Conway Morris (1990b), one of them (specimen "a", see below) was already pictured in Elicki and Schneider (1992) and Elicki (1992) as Archaeooides granulatus Qian, 1977. In view of Conway Morris' discussion it is necessary to revise this assignment (see below). The other 5 specimens are new and first described and figured herein.

\section{PHYLUM, CLASS, ORDER, FAMILY UNCERTAIN}

\section{Genus Aetholicopalla Conway Morris, 1990b}

Type species: Aetholicopalla adnata Conway Morris, 1990b.

\section{Aetholicopalla adnata Conway Morris, 1990b Pl. I, figs. 6-9; Pl. II}

Material: Six specimens from a bioclastic floatstone of a shallow subtidal environment (compare Elicki, 1994, 1996).

Stratigraphic range and occurrence: Upper Ludwigsdorf Member, Marianian (?uppermost Atdabanian-Botoman) by trilobites (Geyer and Elicki, 1995) and early shelly fossils (Elicki, 1994).

\section{Description and discussion}

All specimens ("a"-"f") have a spherical to subspherical shape. Only specimen " $\mathrm{f}$ " (Pl. II, figs. 7, 8) is fully rounded and shows no distinct adaption to a sessil-benthic or encrusting mode of life. The other specimens are encrusted on substrates (see specimens "a" and "b", Pl. I, figs. 6-9) or on other biotas (see specimen "c", Pl. II, figs. 1, 2) or they are at least of a flattend shape (see specimens "c"-"e", Pl. II, figs. 1-6).

\section{Plate II}

Aetholicopalla adnata Conway Morris, 1990b.

1 Specimen «c». The specimen has encrusted shelly parts of another organism (trilobite?). Note also the flattened shape of the globule. Upper Ludwigsdorf Member, Görlitz Syncline. Scale bar $=0.2 \mathrm{~mm}$.

2 Detail of (1). Scale bar $=0.1 \mathrm{~mm}$.

3 Specimen «d». This specimen is only poorly preserved. No double wall structures are visible. Note the flattened shape of the globule. Upper Ludwigsdorf Member, Görlitz Syncline. Scale bar $=0.2 \mathrm{~mm}$.

4 Detail of (3) showing a poorly preserved tubule running into the interior. Scale bar $=0.05 \mathrm{~mm}$.

5 Specimen «e». Well visible is the flattened shape of the globule as well as the subsided upper part. Upper

Ludwigsdorf Member, Görlitz Syncline. Scale bar=0.1 $\mathrm{mm}$.

6 Detail of (5). Note the regular size of the openings. Scale bar $=0.02 \mathrm{~mm}$.

7 Specimen «f». This specimen is well round and shows no flattened shape or encrustings. However, the assignment to Aetholicopalla adnata Conway Morris, $1990 \mathrm{~b}$ is supported by the very well visible tubules which run from the openings on the outer wall into the interior. Upper Ludwigsdorf Member, Görlitz Syncline. Scale bar $=0.1 \mathrm{~mm}$.

8 Detail of (7). Scale bar $=0.1 \mathrm{~mm}$. 
Plate II

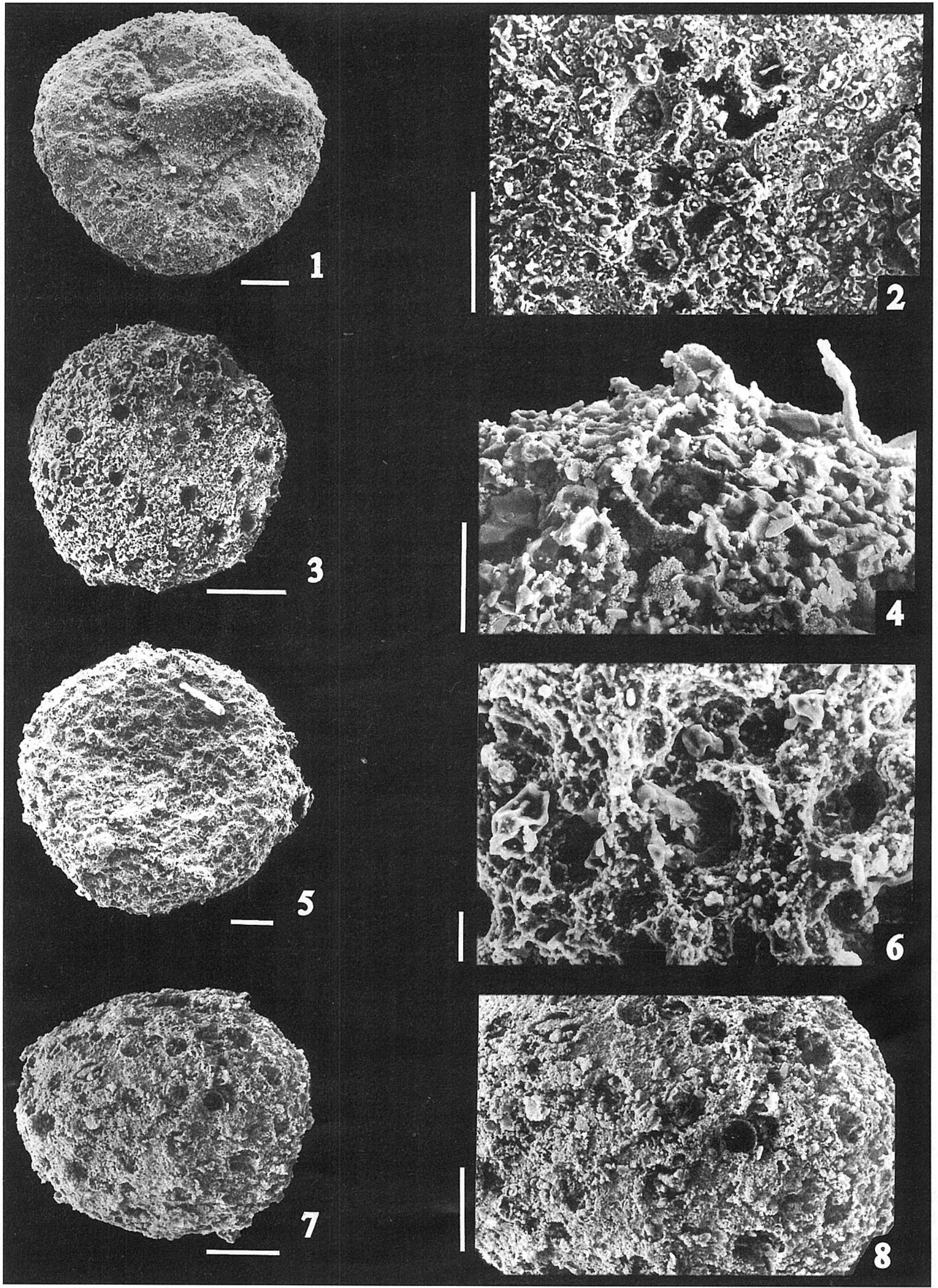

Revista Española de Paleontología, nº extr. Homenaje al Prof. Gonzalo Vidal, 1998. 
A double walled character of the globules can be observed on four specimens: "a"-"c" (Pl. I, figs. 6-9) and "f" (Pl. II, figs. 7, 8). However, the external wall is largely destroyed on all specimens (maybe an effect full of/or intensified by the wet-chemical preparation in the laboratory). Nevertheless, relicts of the external wall are well visible on the globules "a" (Pl. I, figs. 6, 7) and "f" (Pl. II, figs. 7, 8), and (with a minor clearness) also on the two others. On all the specimens circular openings of internal structures are clearly visible. These structures are expressed in best distinction on the specimens "a" and "f". On both the openings form small cones/tubules (more distinct if the external wall is absent, of course). The mean height of the cones is $40 \mu \mathrm{m}-50 \mu \mathrm{m}$ and this represents the distance between the inner and the outer wall. Specimen "f" (Pl. II, figs. 7, 8) is very good to observe that these circular structures are elongated into the interior as tubes. The detailed photograph of specimen "b" (Pl. I, figs. 8, 9) shows also these tubes in the interior of the globule, but now in a longitudinal section. It is also noticeable that the course of the tubes is irregular. The exterior surface of the inner wall (space between the cones) of the globule "a" (Pl. I, figs. 6, 7) is ornamented in a reticulate pattern. This ornamentation can be assumed also for the other specimens, though visible only sometimes due to the poor preservation. All these observations support the assignment of the Görlitz globular fossils to Aetholicopalla adnata Conway Morris, 1990b (for details see below).

$$
\text { Specimen "a" (Pl. I, figs. 6, 7) }
$$

1992 Archaeooides granulatus Qian, 1977; Elicki, pl. 12/1. 1992 Archaeooides granulatus Qian, 1977; Elicki and Schneider, pl. 16/8.

Total diameter: 0.85 x $0.9 \mathrm{~mm}$.

Diameter of tubules: $0.025 \mathrm{~mm}$.

Distance between inner and outer wall: ca. 0.04-0.05 mm (=height of the tubules).

Remarks: This specimen shows all characteristics which are diagnostic for this species. It is very similar to the (better preserved) examples from southern Australia (Bengtson et al., 1990) and from southern France (Kerber, 1988). I agree with Conway Morris (1990b) that the French Archaeooides granulatus Qian, 1977 from the Montagne Noire is more likely Aetholicopalla.

$$
\text { Specimen "b" (Pl. I, figs. 8, 9) }
$$

Total diameter: $1.3 \times 1.5 \mathrm{~mm}$.

Mean diameter of tubules: $0.025 \mathrm{~mm}$.

Remarks: As specimen "a", also this induvidual has all characteristics of the type species, but the preservation is not very good. Remarkable is the longitudinal section of some irregular tubes of the interior. The tubes are of a constant diameter and they run in low angles to the surface. Because the openings on the outer wall are always more or less well circular, it is most likely that these angles became larger near the external wall.

$$
\text { Specimen "c" (Pl. II, figs. 1, 2) }
$$

Total diameter: $1.0 \mathrm{~mm}$.

Mean diameter of "openings": $0.03 \mathrm{~mm}$.

Remarks: A flattened shape and the remain of an encrusted organism (trilobite?) are the most striking features on this specimen. Because of the bad preservation the circular openings or the tubules are not well visible. But based on the other characteristics (see outlines above) specimen "c" is assigned to Aetholicopalla adnata Conway Morris, 1990b.

$$
\text { Specimen "d" (Pl. II, figs. 3, 4) }
$$

Total diameter: $0.5 \mathrm{~mm}$.

Mean diameter of tubules: $0.032 \mathrm{~mm}$.

Remarks: Specimen "d" shows the poorest preservation of all these globules from the Görlitz fauna. No wall structures (except the circular openings) are visible. Any other ornamentation as the two-walled organisation of the globule could not be observed. The occurence (only on single points) of bad preserved tubules, directed into the interior, supports the determination as Aetholicopalla adnata Conway Morris, $1990 \mathrm{~b}$.

$$
\text { Specimen "e” (Pl. II, figs. 5, 6) }
$$

Total diameter: $0.6 \times 0.7 \mathrm{~mm}$.

Mean diameter of "openings": $0.027 \mathrm{~mm}$.

Remarks: On this individual no double-wall structures and no tubules are visible. However, the circular openings on the surface are distinct. The shape of the globule is markedly flattened and one side (upper side?) is subsided.

$$
\text { Specimen "f" (Pl. II, figs. 7, 8) }
$$

Total diameter: $0.3 \times 0.36 \mathrm{~mm}$.

Mean diameter of tubules: $0.021 \mathrm{~mm}$.

Remarks: Specimen "f" differs from the other globules by the well roundness. There are no indications for an attachment of the organism on a substrate or for any encrusting lifestyle. Furthermore, no double-wall structures are visible. So important criteria for Aetholicopalla are not satisfied. This brings specimen "f" nearer to Archaeooides. On the other hand, specimen "f" shows clearly tubules on the external wall and elongated tubes running into the interior which is described from Aetholicopalla. In this example the problem with Aetholicopalla and Archaeooides is explained: the definition and most descriptions of Archaeooides are too imprecise and thus useless for emphatize. In contrast, the definition and the description of Aetholicopalla is very 
detailed. So an equivalent comparison of these two forms is not possible without a revision of the whole stock of these groups. After all, the diagnosis of the genus Aetholicopalla is equivalent to the definition of the only species Aetholicopalla adnata Conway Morris, $1990 \mathrm{~b}$. This is a further reason that requires a critic revision as mentioned above.

Specimen "f" shows the characteristics of both Archaeooides and badly preserved Aetholicopalla, too. Because no such internal structures are hitherto described from Archaeooides, specimen "f" is preliminary assigned to Aetholicopalla adnata Conway Morris, 1990b.

\section{EPILOGUE: THE UTILITY OF POST- BASAL CAMBRIAN SHELLY FAUNAS}

The knowledge on (more or less) Botoman shelly fossils is generally not very good. The biostratigraphical interest in the past was mainly focused on problems of the Precambrian-Cambrian boundary interval than on faunas of higher Lower Cambrian strata. Nevertheless, also Atdabanian fossils are sometimes better investigated in some areas (e.g. Siberian Platform). So the present state of investigations on uppermost AdtabanianBotoman shelly faunas lays still mainly in the sampling and descriptional stage. On the other hand there are some indications that even shelly fossils can be used at least roughly for biostratigraphical divisions also in the higher Lower Cambrian (compare Brasier in Cowie and Brasier, 1989: 122-157). But a much bigger number of investigations are necessary to clarify the real biostratigraphic capability of this polyphylethic group. Nevertheless, these shelly fossils show some other interesting characteristics. When many different fossil bearing horizons are compared, it is conspicuous that the lithological characteristics are relatively often comparable. So it can be assumed that at least a part of "the shelly fossils" depends stronger on the sedimentary facies conditions than other fossil groups. So a second way of further investigations is clearly the analysis of this facial dependence. Maybe the true value of higher Lower Cambrian small shelly fossils is on palaeoecological and phylogenetic aspects. But also in these topics much further work is needed. First steps for the Mediterranean region were and are made by Sdzuy (1969) in Spain and by Kerber (1988) in southern France, as well as by the author (Elicki, 1994) for Germany and — nowadays for southwestern Sardinia.

The analysis of the biostratigraphic and palaeoecological utility of the faunas discussed may complete not only our conception on stratigraphy and correlations; the results may also help to clarify difficult problems on palaeogeography, on depositional history and development of facial belts. An example for such a key-position may exist in the comparison of the Spanish and the German Lower Cambrian. The Lower Cambrian of the Iberian Chains is very similar in the lithological characteristics (and maybe in the sedimentary environments) to the sequence of the Görlitz Lower
Cambrian in Germany. On the other hand, some archaeocyath-dominated sections from Spain resemble German deposits in the Doberlug region (the second area in Germany with fossiliferous Lower Cambrian strata; Fig. 1; Elicki, 1995 and 1997). But, whereas the non archaeocyath-bearing Lower Cambrian of the Iberian Chains can be correlated with the archaeocyath-bearing Spanish Lower Cambrian, such a correlation of the non archaeocyath-bearing Görlitz Lower Cambrian and archaeocyath-bearing Doberlug Lower Cambrian (ca. 100 $\mathrm{km}$ away) is not yet possible because of (1) the lack of archaeocyaths in Görlitz and (2) the inability to prepare Lower Cambrian trilobites from the Doberlug carbonates. So in Germany two different fossil schemes stands opposite to each other. If it should be possible to correlate the biostratigraphic data of trilobites and small shellies and further of archaeocyaths and small shellies in Spain, then it could also be possible to correlate between the different German deposits (or at least to estimate the gap between) on the base of small shellies via the Spanish Lower Cambrian.

Furthermore the investigations on the palaeoecological distribution patterns and on the tendencies in their vertical development within the similar Spanish and German regions can complete one another (and so maybe fill gaps).

Similar working strategies are also imaginable for the other Gondwanan Lower Cambrian deposits in the western Mediterranean (at present, comparing palaeoecological investigations between the Sardinian and the German small shelly faunas are in progress by the author). But the first steps must be the minute investigations and descriptions of the small shelly fossil content of the higher Lower Cambrian strata in this Mediterranean area. The beginning has been done.

\section{ACKNOWLEDGEMENTS}

My warmest thanks go to E. Liñán, J. A. Gámez Vintaned (both Zaragoza), E. Moreno-Eiris (Madrid) and to all the other Spanish colleagues for the very important Field Conference 1996 (Second Field Conference of the Lower Cambrian Stage Subdivision Working Group, Spain), for many discussions there and later and also to an unknown referee for his useful comments to the manuscript. The author's participation on the Spanish field meeting was sponsered by Freiberg University and by the Department of Palaeontology. The present investigations are supported by the German Research Foundation (Project: "Small Shelly Fauna der Campo Pisano Formation SW-Sardiniens"). This paper is a contribution to the I.G.C.P. project 366 "Ecological Aspects of the Cambrian Radiation".

\section{REFERENCES}

Álvaro, J. J. et Vennin, E. 1996. Spicules d'Éponges et Chancelloriidae cambriens des Chaînes Ibériques, NE Espagne. Revue de Micropaléontologie, 39 (4), 293-304. 
Bechstädt, T. and Boni, M. (Eds.) 1994. Sedimentological, stratigraphical and ore deposits field guide of the autochthonous Cambro-Ordovician of southwestern Sardinia. Memoria Descritiva - Carta Geologica d'Italia, $48,1-434$.

Bengtson, S. 1990. Spicules. In: Early Cambrian fossils from South Australia. (Auts. S. Bengtson, S. Conway Morris, B. J. Cooper, P. A. Jell and B. N. Runnegar). Association of Australasian Palaeontologists Memoir, 9 , 24-36.

Bengtson, S. and Conway Morris, S. 1984. A comparative study of Lower Cambrian Halkieria and Middle Cambrian Wiwaxia. Lethaia, 17, 307-329.

Bengtson, S. and Missarzhevski, V. V. 1981. Coeloscleritophora - a major group of enigmatic Cambrian metazoans. United States Geological Survey Open-File Report, 81-743, 19-21.

Bengtson, S., Conway Morris, S., Cooper, B. J., Jell, P. A. and Runnegar, B. N. 1990. Early Cambrian fossils from South Australia. Association of Australasian Palaeontologists Memoir, 9, 1-364.

Bornemann, J. G. 1886. Die Versteinerungen des Cambrischen Schichtensystems der Insel Sardinien Erste Abteilung. Nova Acta der Kaiserlichen Leopoldinisch-Carolinischen Deutschen Akademie der Naturforscher, 51 (1), 3-149.

Bornemann, J. G. 1891. Die Versteinerungen des Cambrischen Schichtensystems der Insel Sardinien Zweite Abteilung. Nova Acta der Kaiserlichen Leopoldinisch-Carolinischen Deutschen Akademie der Naturforscher, 56 (3), 427-529.

Cherchi, A. and Schroeder, R. 1984. Middle Cambrian foraminifera and other microfossils from SW Sardinia. Bolletino della Società Paleontologica Italiana, 23 (2), 149-160.

Chlupáč, I. 1995. Lower Cambrian arthropods from the Paseky Shale (Barrandian area, Czech Republic). Journal of the Czech Geological Society, 40 (4), 9-36.

Chlupáč, I. and Havlíček, V. 1965. Kodymirus n.g., a new aglaspid merostome of the Cambrian of Bohemia. Sborník geologických vèd, Paleontologie, 6, 7-20.

Cobbold, E. S. 1921. The Cambrian horizons of Comley and their Brachiopoda, Pteropoda, Gasteropoda etc. Quarterly Journal of the Geological Society of London, 76, 325-387.

Conway Morris, S. 1990a. Halkieriids. In: Early Cambrian fossils from South Australia. (Auts. S. Bengtson, S. Conway Morris, B. J. Cooper, P. A. Jell and B. N. Runnegar). Association of Australasian Palaeontologists Memoir, 9, 69-103.

Conway Morris, S. 1990b. Spherical fossils of uncertain affinity. In: Early Cambrian fossils from South Australia. (Auts. S. Bengtson, S. Conway Morris, B. J. Cooper, P. A. Jell and B. N. Runnegar). Association of Australasian Palaeontologists Memoir, 9, 333-343.

Conway Morris, S. 1995. Enigmatic shells, possibly halkieriid, from the Middle Cambrian Burgess Shale, British Columbia. Neues Jahrbuch für Geologie und Paläontologie, Abhandlungen, 195 (1-3), 319-331.
Conway Morris, S. and Chapman, A. J. 1997. Lower Cambrian halkieriids and other coeloscleritophorans from Aksu-Wushi, Xinjiang, China. Journal of Palaeontology, 71 (1), 6-22.

Conway Morris, S. and Chen Menge 1990. Blastulospongia polytreta $\mathrm{n}$. sp., an enigmatic organism from the Lower Cambrian of Hubei, China. Journal of Paleontology, 64 (1), 26-30.

Conway Morris, S. and Peel, J. S. 1990. Articulated halkieriids from the Lower Cambrian of North Greenland. Nature, 345 (6278), 802-805.

Courjault-Radé, P. 1988. Analyse sédimentologique de la formation de l'Orbiel ("alternance gréso-calcaire" autc., Cambrien inférieur). Évolution tectono-sédimentaire et climatique (versant sud de la Montagne Noire, Massif Central, France). Bulletin de la Société géologique de France, 8ème série, 4 (6), 1003-1013.

Courjault-Radé, P., Debrenne, F. and Gandin, A. 1992. Palaeogeographic geodynamic evolution of the Gondwana continental margins during the Cambrian. Terra Nova, 4, 657-667.

Cowie, J. W. and Brasier, M. D. (Eds.) 1989. The Precambrian-Cambrian boundary. Oxford Monographs on Geology and Geophysics, 12, Clarendon Press, Oxford. 213 pp.

Doré, F. 1969. Les formations cambriennes de Normandie. Thèse de Doctorat d'État, Université de Caen. [Unpublished.]

Doré, F. et Reid, R. E. 1965. Allonia tripodophora nov. gen, nov. sp., nouvelle éponge du Cambrien inférieur de Carteret (Manche). Comptes Rendus Sommaires des Séances de la Société géologique de France, 1965, 2021.

Elicki, O. 1992. Faziesanalyse der kambrischen Karbonate Deutschlands. Dissertation, Technische Universität Freiberg. 174 pp. [Unpublished.]

Elicki, O. 1994. Lower Cambrian carbonates from eastern Germany: palaeontology, stratigraphy and palaeogeography. Neues Jahrbuch für Geologie und Palaeontologie, Abhandlungen, 191 (1), 69-93.

Elicki, O. 1996. Die Gastropoden und Monoplacophoren der unterkambrischen Görlitz-Fauna. Freiberger Forschungsheft, C 464 - Paläontologie, Stratigraphie Fazies, Heft 3, 145-173.

Elicki, O. 1997. Biostratigraphic data of the German Cambrian - present state of knowledge. Freiberger Forschungsheft, C 466 - Paläontologie, Stratigraphie Fazies, Heft 4, 155-165.

Elicki, O. and Debrenne, F. 1993. The archaeocyatha of Germany. Freiberger Forschungsheft, C 450 Paläontologie, Stratigraphie Fazies, Heft 1, 3-40.

Elicki, O. and Schneider, J. 1992. Lower Cambrian (Atdabanian/Botomian) shallow-marine carbonates of the Görlitz Synclinorium (Saxony/Germany). Facies, 26, 55-66.

Fatka, O. and Konzalova, M. 1995. Microfossils of the Paseky Shale (Lower Cambrian, Czech Republic). Journal of the Czech Geological Society, 40 (4), 55-66.

Fernández-Remolar, D. C. 1996. Los microfósiles problemáticos del Cámbrico Inferior de la Sierra de 
Córdoba: datos preliminares. Coloquios de Paleontología, 48, 161-173.

Geyer, G. and Elicki, O. 1995. Lower Cambrian trilobites from the Görlitz Synclinorium (Germany) - review and new results. Paläontologische Zeitschrift, 69 (1/2), 87119.

Gèze, B. 1956. Les terrains Cambriens et antécambriens dans le sud du Massif Central français (Montagne Noire et Cévennes méridionales). In: XX Congreso Geológico Internacional, México. El sistema Cámbrico, su paleogeografía y el problema de su base. Symposium, 185-234.

Gürich, G. 1929. Silesicaris von Leipe und Phyllocariden überhaupt. Mitteilungen des Geologischen Staatsinstitutes in Hamburg, 11, 21-90.

Hall, J. 1847. Natural history of New York. Paleontology: Volume 1. Containing descriptions of the organic remains of the lower division of the New-York System. C. van Benthuysen, Albany. 388 pp.

Jell, P. A. 1981. Thambetolepis delicata gen. et sp. nov., an enigmatic fossil from the Early Cambrian of South Australia. Alcheringa, 5, 85-93.

Kerber, M. 1988. Mikrofossilien aus unterkambrischen Gesteinen der Montagne Noire, Frankreich. Palaeontographica, Abteilung A, 202, 127-203.

Kowalski, W. R. 1983. Stratigraphy of the Upper Precambrian and lowest Cambrian strata in southern Poland. Acta Geologica Polonica. 33 (1-4), 183-218.

Kruse, P. D. 1990. Cambrian palaeontology of the Daly Basin. Northern Territory Geological Survey Report, 7, $1-58$.

Landing, E., Myrow, P., Benus, P. and Narbonne, G. M. 1989. The Placentian Series: appearance of the oldest skeletalized faunas in southeastern Newfoundland. Journal of Palaeontology, 63 (6), 739-769.

Lendzion, K., MoczydXowska, M. and Zakowa, H. 1982. A new look at the Bazow Cambrian sequence (southern Holy Cross Mountains). Bulletin de l'Académie Polonaise des Sciences, Série des Sciences de la Terre, 30 (1-2), 67-75.

Liñán, E. and Gámez-Vintaned, J. A. 1993. Lower Cambrian palaeogeography of the Iberian Peninsula and its relations with some neighbouring European areas. Bulletin de la Société géologique de France, 164 (6), 831-842.

Liñán, E. and Quesada, C. 1990. Part V: Ossa-Morena Zone. 2: Stratigraphy. 2-2: Rift Phase (Cambrian). In: PreMesozoic Geology of Iberia. (Eds. R. D. Dallmeyer and E. Martínez García. Springer-Verlag, Berlin, Heidelberg, New York, 259-266.

Liñán, E., Perejón, A. and Sdzuy, K. 1993. The LowerMiddle Cambrian stages and stratotypes from the Iberian Peninsula: a revision. Geological Magazine, 130 (6), 817-833.

Luo Huilin, Jiang Zhiwen, Wu Xiche, Song Xueliang and Ouyang Lin. (Eds.) 1982. The Sinian-Cambrian boundary in eastern Yunnan, China. People's Publishing House, Beijing. 225 pp. [In Chinese.]

Matthew, G. F. 1899. Studies on Cambrian faunas. 3. Upper Cambrian fauna of Mount Stephen, British Columbia -
The trilobites and worms. Royal Society of Canada, Proceedings and Transactions, Section II, 5, 39-66.

Matthews, S. C. and Missarzhevski, V. V. 1975. Small shelly fossils of late Precambrian and early Cambrian age: a review of recent work. Journal of the Geological Society of London, 131, 289-304.

Missarzhevski, V. V. 1981. Ranne kembrijskie hiolity i gastropody Mongolii. [Early Cambrian hyoliths and gastropods from Mongolia.] Paleontologicheskij Zhurnal, 1981 (1), 21-28. [In Russian.]

Missarzhevski, V. V. 1989. Drevnejshaja skeletnaja fauna i stratigrafija sloev na granitse dokembrija i kembrija. [Oldest skeletal fossils and stratigraphy of Precambrian and Cambrian boundary beds.] Trudy Geologicheskogo Instituta, Akademija nauk SSSR, 443, 1-240. [In Russian.]

Mostler, H. 1985. Neue heteractinide Spongien (Calcispongea) aus dem Unter- und Mittelkambrium Südwestsardiniens. Berichte des naturwissenschaftlichmedezinischen Vereins Innsbruck, 72, 7-32.

OrXowski, S. 1975. Cambrian and upper Precambrian lithostratigraphic units in the Holy Cross Mountains. Acta Geologica Polonica, 25 (3), 431-448.

Orłowski, S. 1985. Lower Cambrian and its trilobites in the Holy Cross Mountains. Acta Geologica Polonica, 35 (34), 231-250.

OrXowski, S. and Waksmundzki, B. 1986. The oldest Hyolitha in the Lower Cambrian of the Holy Cross Mountains. Acta Geologica Polonica, 36 (1-3), 225231.

Picket, J. and Jell, P. A. 1983. Middle Cambrian Sphinctozoa (Porifera) from New South Wales. Association of Australasian Palaeontologists Memoir, 1, 85-92.

Pillola, G. L. 1991. Trilobites du Cambrien inférieur du SW de la Sardaigne, Italie. Palaeontographica Italica, 78, 1174.

Pillola, G. L. 1993. The Lower Cambrian trilobite Bigotina and allied genera. Palaeontology, 36 (4), 855-881.

Poulsen, C. 1967. Fossils from the Lower Cambrian of Bornholm. Det Kongelige Danske Videnskabernes Selskab, Matematisk-Fysiske Meddelelser, 36 (2), 1-48.

Qian Yi. 1977. Hyolitha and some problematica from the Lower Cambrian Meishucun Stage in central and SW China. Acta Palaeontologica Sinica, 16 (2), 255-278. [In Chinese with English abstract.]

Qian Yi and Bengtson, S. 1989. Palaeontology and biostratigraphy of the Early Cambrian Meishucunian stage in Yunnan province, South China. Fossils and Strata, 24, 1-156.

Richter, R. und E. Richter, E. 1923. Eine kambrische Fauna im Niederschlesischen Schiefergebirge. Centralblatt für Mineralogie, Geologie und Paläontologie, Beilagenband 1923 (23), 730-735.

Richter, R. und E. Richter, E. 1941. Die Fauna des Unterkambriums von Cala in Andalusien. Abhandlungen der Senckenbergischen Naturforschenden Gesellschaft, 455, 1-90.

Rozanov, A. Yu. 1982. Granitsa dokembrija/kembrija v geosinklinal'nykh oblastjakh (opornye razrezy Salany 
Gol, Narodnaja Respublika Mongolija). [The Precambrian/Cambrian boundary in the geosynclinal areas (the reference section of Salany-Gol, Peoples Republic of Mongolia).] Nauka, Moskva. 162 pp. [In Russian.]

Schwarzbach, M. 1934. Das Cambrium der Oberlausitz. Abhandlungen der Naturforschenden Gesellschaft Görlitz, 32 (2), 7-54.

Schwarzbach, M. 1939. Die Oberlausitzer Protolenusfauna. Weitere Funde aus dem schlesischen Kambrium und ihre allgemeine Bedeutung. Jahrbuch der preußischen geologischen Landesanstalt, 59, 769-785.

Sdzuy, K. 1969. Unter- und Mittelkambrische Porifera
(Chancelloria und Hexactinellida). Paläontologische Zeitschrift, 43, 115-147.

Storch, P., Fatka, O. and Kraft, P. 1993. Lower Palaeozoic of the Barrandian area (Czech Republic) - a review. Coloquios de Paleontología, 45, 163-191.

Val'kov, A. K. 1987. Biostratigrafija nizhnego Kembrija vostoka Sibirskoj platformy, Yudoma-Olenekskaja oblast'. [Lower Cambrian biostratigraphy of the eastern Siberian platform, Yudoma-Olenek region.] Nauka, Moskva. 136 pp. [In Russian.]

Walcott, C. D. 1890. Descriptive notes of new genera and species from the Lower Cambrian or Olenellus Zone of North America. U. S. National Museum Proceedings, 12 (1889), 33-46. 